\title{
Using fecal profiles of bile acids to assess habitat use by threatened carnivores in the Maulino forest of central Chile
}

\author{
Empleo del perfil de ácidos biliares fecales para evaluar uso del hábitat por carnívoros \\ amenazados en el bosque maulino de Chile central
}

\section{CARLA GUERRERO, LUIS ESPINOZA ${ }^{1}$, HERMANN M. NIEMEYER \& JAVIER A. SIMONETTI ${ }^{*}$}

\author{
Departamento de Ciencias Ecológicas, Facultad de Ciencias, Universidad de Chile, Casilla 653, Santiago, Chile \\ ${ }^{1}$ Current address: Departamento de Química, Universidad Técnica Federico Santa María, Casilla 110v, Valparaíso, Chile; \\ *e-mail of corresponding author: jsimonet@uchile.cl
}

\begin{abstract}
The distribution and habitat use by carnivores can be assessed by studying their tracks or feces. If these methods are to be used confidently, they should not only unequivocally discriminate among species, but should also render the same patterns of spatial distributions. We assessed the fulfillment of these requirements with five carnivores inhabiting the Maulino forest of central Chile: Galictis cuja, Oncifelis guigna, Pseudalopex culpaeus, Pseudalopex griseus, and Puma concolor. Fecal bile acid thin layer chromatographic profiles were assessed, and shown to be species-specific, invariant within samples of a given individual and among individuals of a given species, but consistently different across species. The spatial distribution of feces in mixed stands of native forests and exotic pine plantations in the coastal Maule region of central Chile was compared with the expected distribution according to habitat offer, and also with the expected distribution based on earlier track records. The results revealed that Pseudalopex culpaeus makes extensive use of pine plantations; Oncifelis guigna prefers native forests, and Pseudalopex griseus thrives in pine plantations, native forests, and patches of native forest, in proportion to habitat availability. Results from scat distribution were similar to those obtained by tracks records. Feces and tracks were thus useful indicators of habitat use by carnivores, and could be used complementarily to study species with conservation problems.
\end{abstract}

Key words: fecal bile acids, Galictis, habitat use, Oncifelis, Pseudalopex, Puma, thin layer chromatography.

\section{RESUMEN}

El uso del hábitat por carnívoros puede ser examinado a partir de la distribución de sus huellas y fecas. Para que ambas aproximaciones sean usadas en forma segura y complementaria, ellas deberían no solamente discriminar inequívocamente entre especies, sino que también deberían entregar la misma información sobre los patrones de distribución espacial. Analizamos el cumplimiento de estos requisitos con cinco especies de carnívoros en el bosque maulino de Chile central: Galictis cuja, Oncifelis guigna, Pseudalopex culpaeus, Pseudalopex griseus y Puma concolor. Los perfiles de ácidos biliares fecales, establecidos mediante cromatografía de capa fina, resultaron ser especie-específicos, invariantes tanto dentro de muestras de un mismo individuo como entre muestras de diferentes individuos de una misma especie, pero son consistentemente diferentes entre especies. La distribución especial de fecas en áreas de bosque nativo y plantaciones de pino en el bosque costero del Maule se comparó con la distribución esperada en base a estudios previos basados en registro de huellas. Pseudalopex culpaeus usa extensamente plantaciones de pino; Oncifelis guigna prefiere bosque nativo y Pseudalopex griseus usa bosque nativo y plantaciones de pino en proporción a su disponibilidad. Los resultados de la distribución de fecas son similares a los obtenidos por registro de huellas.

Palabras clave: ácidos biliares fecales, cromatografía en capa fina, Galictis, Oncifelis, Pseudalopex, Puma, uso de hábitat.

\section{INTRODUCTION}

Chilean carnivores, particularly those inhabiting central Chile are of conservation concern. Habitat changes and illegal hunting have decimated populations, threatening their survival (Miller et al. 1983). Sound conservation practices require to properly 
assess habitat use by target species. This is particularly true for carnivores inhabiting the Maulino forest, a severely reduced and shrinking forest (Grez et al. 1997). Here, Oncifelis guigna, the smallest known cat, endemic to Nothofagus forests, prefers habitats with dense bush cover and is almost exclusively restricted to native forests, while Pseudalopex culpaeus uses open habitats, close to roads, including Monterrrey pine plantations (Pinus radiata; Acosta-Jamett \& Simonetti 2004). This pattern of habitat use is based on a handful of track records despite a significant sampling effort devoted to assess habitat use (Acosta \& Simonetti 1999, Acosta-Jamett \& Simonetti 2004). Therefore, another indicator of their presence is required to confirm the pattern of habitat use by these and other threatened carnivores of the Maulino forest, including Galictis cuja, Pseudalopex griseus, and Puma concolor, all of conservation concern (Miller et al. 1983).

Besides tracks, carnivores can be recognized through their profiles of fecal bile acids, which are species-specific (Haslewood 1967). The technique has been used with varying degrees of success. Major et al. (1980) and Johnson et al. (1984) used it to assess the distribution and abundance of carnivores in different habitats in North America, while Capurro et al. (1997), Fernández et al. (1997), and Cazón \& Suhring (1998) used it to identify several Neotropical carnivore species. However, Jiménez et al. (1996a) were unable to distinguish feces from $P$. culpaeus and $P$. griseus in Chile, two species that were nevertheless distinguished by Capurro et al. (1997). Here, our aim is two-fold. First, we explore if carnivores inhabiting the Maulino forest can be unequivocally recognized by their bile acid patterns. If species can be recognized, each feces can be used as an indicator of an animal presence in a given habitat, enabling the use of such record to reinforce assessment based by other means, such as track records. Second, we test if the pattern of habitat use as depicted by the spatial distribution of feces is similar to the pattern assessed based on track records. If patterns depicted by these two different types of evidence are similar, they can reinforce each other, providing more robust estimates of habitat use.

\section{MATERIAL AND METHODS}

\section{Chemical analysis}

The analytical method, developed using feces from animals in captivity followed Major et al. (1980). Powdered dry feces (3 g) were extracted with dichloromethane: methanol $(1: 1$; $18 \mathrm{~mL})$. The organic extract was filtered, concentrated to $3 \mathrm{~mL}$, and redissolved in ethyl acetate $(30 \mathrm{~mL})$ before being subjected to alkaline extraction ( $3 \times 20 \mathrm{~mL}$ of $4 \mathrm{~N} \mathrm{NaOH})$ in order to purify the bile acids from other lipophilic steroidal compounds. The alkaline extract was neutralized and extracted with ethyl acetate $(3 \times 20 \mathrm{~mL})$. This new organic extract was washed with saturated $\mathrm{NaHCO}_{3}(3$ x 20 $\mathrm{mL})$, and water $(3 \times 20 \mathrm{~mL})$, and dried over anhydrous $\mathrm{MgSO}_{4}$. The resulting solution was spotted $(50 \mu \mathrm{L})$ on thin-layer chromatographic plates (Merck, Silica Gel 60 WF254, 10 x 10 $\mathrm{cm})$ which were eluted with a mixture of hexane: methyl-ethyl ketone: acetic acid (56:36:8). The plates were developed by spraying on them a mixture consisting of $80 \mathrm{~mL}$ glacial acetic acid, $16 \mathrm{~mL}$ water, $4 \mathrm{~mL}$ sulfuric acid and $0.53,4-$ dimethoxybenzaldehyde, and heating to $100{ }^{\circ} \mathrm{C}$ for 3 min. Bile acids were identified by comparison of their $\mathrm{R}_{\mathrm{f}}$ values and color with those of commercially available standards of cholic, dehydrocholic, deoxycholic, hyodeoxycholic, lithocholic, chenodeoxycholic, and ursocholic acids, and cholesterol (Sigma Chemical Co.). The $\mathrm{Rf}$ value is the ratio of the distance traveled by a compound relative to the distance traveled by the solvent front in the chromatographic plate.

\section{Samples from captive animals}

Feces were obtained from captive animals at Santiago's Metropolitan Zoo, Temuco's Zoo and, and Cajón del Maipo-CODEFF Rehabilitation Center. Six feces were analyzed from each of the following species: $P$. concolor, $P$. culpaeus and $P$. griseus, and two feces were analyzed from each of the following species: $G$. cuja and O. guigna. Feces can not be assigned to any given individual as two or more specimens shared the same exhibit cage, excepting $O$. guigna who was the single captive individual in all Chilean zoos. Thus, each scat could not be associated to the sex of the producer. However, 
sex has been shown to infuence concentration but not composition of bile acids in feces (e.g., Hellou et al. 1988). On the other hand, only fiber-rich diets could decrease the incidence and concentration of fecal bile acids (Quinn \& Jackman 1994). This was not the case in either captive or in wild animals at the study area: captive carnivores were fed with livestock remains while wild carnivores largely prey upon small mammals and invertebrates, with a low consumption of plant items, mostly seeds (J.A. Simonetti personal observations, Correa \& Roa 2005). Each scat was divided into three subsamples, which were extracted and analyzed independently.

\section{Collection of field samples}

Sixty-three unknown feces were collected from three different habitats in Tregualemu, coastal central Chile: continuous native forest (Los Queules National Reserve and adjoining forests of private lands), patches of native forest, and commercial pine ( $P$. radiata) plantations (Acosta-Jamett \& Simonetti 2004). The study area covered 680 ha, 230 of which (34\%) were continuous forest, 120 ha $(18 \%)$ were fragments of native forests scattered in the landscape, usually surrounded by Pinus radiata plantations. Isolated remnants of native forests ranged from 1 to 10 ha. Plantations covered 330 ha $(48 \%)$ of the study site, stands ranging from 33 to $<150$ ha (Acosta-Jamett \& Simonetti 2004).

Feces were collected from September 1998 to January 2002, while surveying each type of habitat. Feces were placed in paper bags and air-dried, and stored in paper bags until used. Fecal bile acids are stable to environmental conditions and to long storage periods enabling to confidently use the available sample (Lin et al. 1978, Fernández et al. 1997). Sampling effort (hour/person/day) devoted to collect feces was proportional to habitat availability (Acosta-Jamett \& Simonetti 2004). Such sampling allows deriving a "no-preference" expectation assuming animals do not prefer any recognized habitat type. If such were the case, the relative abundance of feces should be in proportion to the abundance of each habitat type (e.g., Price \& Kramer 1984).

The assessment of habitat use by carnivores based on tracks was performed in the same area where feces were collected. Habitat use by carnivores was assessed by Acosta-Jamett \& Simonetti (2004) through the scent-station method (Roughton \& Sweeny 1982). The relative use of continuous forest, forest fragments and pine plantations was estimated as the number of stations with animal tracks over a total of 32 scent-stations installed in accordance with the relative abundance of the different habitat types across the landscape. A total sampling effort of 620 sampling stations night $^{-1}$ rendered 58 tracks, of which $77 \%$ of $O$. guigna tracks were recorded in continuous forest, $15 \%$ in forest remnants and $8 \%$ in pine plantations. Regarding foxes, $21 \%$ of tracks of $P$. culpaeus were recorded in continuous forest, $4 \%$ in forest remnants and $75 \%$ in pine plantations, respectively (Acosta-Jamett \& Simonetti 2004).

\section{Statistical analysis}

Similarity in bile acid composition was assessed through the Jaccard index (Krebs 1989). Comparisons between sub-samples and between individuals of the same species should give a value of 1.0 (complete similarity), and comparison between different species should give values smaller than 1.0 (partial similarity).

The observed location of scats in different habitats (native forest, patches of native forest, and pine plantations) was compared in relation to (a) the use predicted on the basis of the availability of the different habitats, using a Gtest. If animals use habitats randomly, feces distribution should be proportional to habitat availability; otherwise, it should suggest habitat selection. (b) The pattern of habitat use assessed also was compared with the assessment based on track records (see AcostaJamett \& Simonetti 2004), using a G-test. If both types of evidences convey similar results, no statistically difference ought to be observed.

\section{RESULTS}

The five carnivore species produced unique fecal bile acid patterns (Table 1). Six of the seven bile acid standards used were detected in some or all of the samples. Ursocholic acid was not detected in any species. Some acids, like cholic acid, were detected in all species while others were 
recorded in only one species, like dehydrocholic acid in G. cuja. Three unidentified spots, presumably bile acids on the basis of extraction and purification procedures, $\mathrm{R}_{\mathrm{f}}$ values, and color of spots, were detected in some of the samples. Cholesterol was present in all the samples as a purple spot with $\mathrm{R}_{\mathrm{f}}$ value of 0.8 .

Pseudalopex culpaeus differed from $P$. griseus by the presence in the former of deoxycholic and chenodeoxycholic acids. Puma concolor differed from $O$. guigna by the presence of hyodeoxycholic acid only in $P$. concolor. Only G. cuja showed dehydrocholic acid and the unknown compound X1 (Table 1). Only the felids exhibited unknown compound X2 (Table 1).

Bile acid profiles of sub-samples from any given individual were always identical (Jaccard index of 1.0 in all cases). Likewise, the composition of extracts from different individuals of the same species was invariable (Jaccard index of 1.0 in all cases). When comparing different species, Jaccard indexes were always smaller than 1.0. Jaccard indexes for intraspecific comparisons were significantly larger than for interspecific comparisons $(\mathrm{U}=3.06, \mathrm{P}=0.002)$, demonstrating that bile acid profiles are characteristic of each carnivore species.

The Jaccard index for comparisons between the different species of carnivores studied varied between 0.44 and 0.86 (Table 2). Relative similarity in the profile of bile acids did not follow phylogenetic relatedness among species. Thus, the bile acid profile for $P$. culpaeus was more similar to that of $P$. concolor or $O$. guigna than to that of congeneric $P$. griseus. On the other hand, the profile of $P$. griseus was more similar to that of $P$. culpaeus that to any of the other species, and the felids (P. concolor and O. guigna) showed the greatest degree of similarity.

All but three of the sixty-three field collected fecal samples could be unequivocally assigned to one of the known species. The profiles of the three odd samples did not match exactly with those of any of the species studied, and might belong to other carnivore, such as a domestic species. These samples were excluded from the analysis of habitat use (Table 1).

Twenty feces were assigned to $O$. guigna, 26 to $P$. culpaeus, 14 to $P$. griseus and 3 to $G$. cuja; no scat was assigned to $P$. concolor. Most feces from $O$. guigna were found in the native forest. This distribution was significantly different from that expected on the basis of relative occurrence of each habitat in the area sampled; hence, O. guigna prefers continuous native forests over forest fragments or pine plantations (Table 3). Feces from $P$. culpaeus were found in pine plantations in numbers

\section{TABLE 1}

Bile acids present in feces extracts of different carnivores: Galictis cuja, Pseudalopex culpaeus, Pseusalopex griseus, Oncifelis guigna y Puma concolor, according to thin-layer chromatography technique, color and $\mathrm{R}_{\mathrm{f}}$ value of spots. Presence or absence are indicated by "+" and "-“", respectively. Abbreviations for bile acids are as follows: Coi (cholic), Deh (dehydrocholic), Hyd (hyodeoxycholic), Deo (deoxycholic), Che (chenodeoxycholic), Lit (lithocholic), X1, X2 and X3 (unknown components)

Ácidos biliares presentes en fecas de diferentes carnívoros: Galictis cuja, Pseudalopex culpaeus, Pseusalopex griseus,

Oncifelis guigna y Puma concolor, de acuerdo a la técnica de cromatografía en capa fina, color y $\mathrm{R}_{\mathrm{f}}$ de las manchas. Presencia o ausencia de un ácido se indican como "+” y “_", respectivamente. Acronismos para los ácidos biliares son: Coi (cólico), Deh (dehidro cólico), Hyd (hiodeoxi cólico), Deo (deoxi cólico), Che (quenodeoxi cólico), Lit (lito cólico), X1, X2 y X3 (compuestos desconocidos)

\begin{tabular}{lccccccccc}
\hline $\begin{array}{l}\text { Bile acid } \\
\mathrm{R}_{\mathrm{f}} \text { Color }\end{array}$ & $\begin{array}{c}\text { Coi } 0.17 \\
\text { Brown }\end{array}$ & $\begin{array}{c}\text { Hyd 0.30 } \\
\text { Violet }\end{array}$ & $\begin{array}{c}\text { X1 0.34 } \\
\text { Orange }\end{array}$ & $\begin{array}{c}\text { Che } 0.46 \\
\text { Blue }\end{array}$ & $\begin{array}{c}\text { Deh 0.50 } \\
\text { Orange }\end{array}$ & $\begin{array}{c}\text { Deo 0.55 } \\
\text { Brown }\end{array}$ & $\begin{array}{c}\text { X2 0.57 } \\
\text { Brown }\end{array}$ & $\begin{array}{c}\text { X3 } 0.61 \\
\text { Yellow }\end{array}$ & $\begin{array}{c}\text { Lit } 0.71 \\
\text { Violet }\end{array}$ \\
\hline P. culpaeus & + & + & - & + & - & + & - & + & + \\
P. griseus & + & - & - & - & - & + & - & + & + \\
P. concolor & + & + & - & + & - & + & + & + & + \\
O. guigna & + & - & - & + & - & + & + & + & + \\
G. cuja & + & + & + & - & + & + & - & + & + \\
\hline
\end{tabular}


TABLE 2

Jaccard index for comparisons of fecal bile acid composition between Galictis cuja, Pseudalopex culpaeus, Pseusalopex griseus, Oncifelis guigna y Puma concolor

Índice de Jaccard para comparaciones en la composición de ácidos biliares entre Galictis cuja, Pseudalopex culpaeus, Pseudalopex griseus, Oncifelis guigna y Puma concolor

\begin{tabular}{lccccc}
\hline & P. culpaeus & P. griseus & P. concolor & O. guigna & G. cuja \\
\hline P. culpaeus & \multirow{2}{*}{1.00} & 0.67 & 0.86 & 0.71 & 0.62 \\
P. griseus & & 1.00 & 0.57 & 0.57 & 0.57 \\
P. concolor & & 1.00 & 0.86 & 0.56 \\
O. guigna & & & 1.00 & 0.44 \\
G. cuja & & & & 1.00 \\
\hline
\end{tabular}

higher than expected on the basis of habitat offer; hence $P$. culpaeus shows a preference for pine plantations. Most feces of $P$. griseus were found in pine plantations; however, the numbers were not significantly different from the habitat offer, suggesting that $P$. griseus does not have particular preferences for a given habitat (Table 3). The low number of feces collected from $G$. cuja precluded a study of its habitat use.

No significant difference was detected between the spatial use of $O$. guigna and $P$. culpaeus based on the distribution of their feces and that recorded based on the distribution of their tracks -obtained by Acosta-Jamett \& Simonetti (2004)- (Table 4). That is, the two types of evidence convey the same pattern of habitat use by these two carnivores.

\section{DISCUSSION}

The analysis by thin layer chromatography of fecal bile acids proves to be an effective technique to study habitat use by Chilean carnivores. Species can be unequivocally assigned to the species level. Thus, contrary to the study of Jiménez et al. (1996a), the method described herein may be used to distinguish bile profiles from $P$. griseus and $P$. culpaeus, most likely on account of the pre-purification of bile acids by extracting them with an alkaline solvent. In fact, our analysis provides the first evidence of the presence of $P$. griseus in the coastal Maulino forest of central Chile and its sympatry with $P$. culpaeus. A previous study based on the observation of tracks (AcostaJamett \& Simonetti 2004) unraveled only the presence of $P$. culpaeus. A lower abundance of $P$. griseus might have precluded its detection through tracks. Sympatry of these foxes though, seems more common than previously thought. Usually, $P$. culpaeus and $P$. griseus were regarded as allopatric, but cases of sympatry and parapatry have been frequently discovered, suggesting that this phenomenon might be more common than hitherto detected (e.g., Johnson \& Franklin 1994, Jiménez et al. 1996b).

The pattern of habitat use obtained with feces from $O$. guigna and $P$. culpaeus is similar to the spatial distribution of their tracks (Acosta-Jamett \& Simonetti 2004). Thus, both indicators (feces and tracks) render similar information regarding habitat use by these carnivores, strengthening current assessments of habitat distribution. The comparison of feces distribution with habitat surface available in the area studied showed that $O$. guigna preferred native forest over pine plantations and patches of native forest. This is consistent with its preference for habitats with dense bush cover, far from roads, and close to large patches of forest as assessed by tracks (Acosta-Jamett \& Simonetti 2004). Regarding P. culpaeus, it apparently preferred pine plantations, possible due to increased abundance of its main prey, small mammals (Saavedra \& Simonetti in press). Therefore, everything else being equal, $O$. guigna would be more severely affected than foxes by ongoing landscape changes. 
TABLE 3

Number of feces found (obs) compared with number expected on the basis of habitat resource (exp) Número de fecas encontradas (obs) comparadas con el número de fecas esperado en función de la disponibilidad de hábitat (exp)

\begin{tabular}{lcccccc}
\hline Species & \multicolumn{3}{c}{ Habitat } & Total & G-value & P-value \\
\cline { 2 - 5 } & $\begin{array}{c}\text { Pine plantations } \\
\text { (obs/exp) }\end{array}$ & $\begin{array}{c}\text { Native forest } \\
\text { (obs/exp) }\end{array}$ & $\begin{array}{c}\text { Patches of native } \\
\text { forest (obs/exp) }\end{array}$ & & & \\
\hline O. guigna & $4 / 9.6$ & $12 / 6.8$ & $4 / 3.6$ & 20 & 7.50 & 0.025 \\
P. culpaeus & $20 / 12$ & $5 / 9$ & $1 / 5$ & 26 & 11.34 & 0.005 \\
$P$. griseus & $10 / 6.7$ & $3 / 4.8$ & $1 / 2.5$ & 14 & 3.41 & 0.250 \\
\hline
\end{tabular}

TABLE 4

Number of feces found (obs) compared with number expected (exp) on the basis of tracks registered by Acosta-Jamett \& Simonetti (2004)

Número de fecas encontradas (obs) comparadas con el número esperado (exp) en función del número de huellas registradas por Acosta-Jamett \& Simonetti (2004)

\begin{tabular}{lcccccc}
\hline Species & \multicolumn{3}{c}{ Habitat } & Total & G-value & P-value \\
\cline { 2 - 5 } & $\begin{array}{c}\text { Pine plantations } \\
\text { (obs/exp) }\end{array}$ & $\begin{array}{c}\text { Native forest } \\
\text { (obs/exp) }\end{array}$ & $\begin{array}{c}\text { Patches of native } \\
\text { forest (obs/exp) }\end{array}$ & & & \\
\hline O. guigna & $4 / 2$ & $12 / 15$ & $4 / 3$ & 20 & 2.50 & 0.50 \\
P. culpaeus & $20 / 20$ & $5 / 5$ & $1 / 1$ & 26 & 0.00 & 1.00 \\
\hline
\end{tabular}

The conservation of endangered carnivores such as $O$. guigna in the coastal Maulino forest requires to be based in solid empirical evidence (Acosta-Jamett et al. 2003, Simonetti et al. 2002). The validity of bile acids in feces to differentiate closely related species and hence to assess habitat use and the congruence in data obtained from feces and tracks, offers more robust data upon which to elaborate a conservation strategy of the carnivores of coastal central Chile.

\section{ACKNOWLEDGEMENTS}

Feces of known sources were provided by $\mathrm{J}$. Navarro (Temuco Zoo), P. Pascual (Metropolitan Zoo), and B. Zentilli (CODEFF). We are grateful to the Chilean Forest Service (CONAF) and Forestal Terranova S.A. which allowed us to work at the Los Queules National Reserve and their state, respectively. This research was partially funded by a Presidential Chair in Sciences to HMN, and FONDECYT 1981050 and 1010852 to JAS.

\section{LITERATURE CITED}

ACOSTA GA \& JA SIMONETTI (1999) Guía de huellas de once especies de mamíferos del bosque templado chileno. Boletín del Museo Nacional de Historia Natural (Chile) 48: 19-27.

ACOSTA-JAMETT G \& JA SIMONETTI (2004) Habitat use by Oncifelis guiga and Pseudalopex culpaeus in a fragmented forest landscape in central Chile. Biodiversity and Conservation 13: 1135-1151.

ACOSTA-JAMETT G, JA SIMONETTI, RO BUSTAMANTE \& N DUNSTONE (2003) Metapopulation approach to assess survival of Oncifelis guigna in fragmented forests of central Chile: a theoretical model. Mastozoología Neotropical (Argentina) 10: 217-229.

CAPURRO AF, AJ NOVARO, A TRAVAINI \& M ROMERO (1997) Improved bile acid thin layer chromatography to identify feces of Neotropical carnivores. Journal of Wildlife Management 61: 1424-1427.

CAZÓN A \& SS SUHRING (1998) A technique for extraction and thin layer chromatography visualization of fecal bile acids applied to Neotropical felids scats. Revista de Biología Tropical (Costa Rica) 47: 245-249.

CORREA P \& A ROA (2005) Relaciones tróficas entre Oncifelis guigna, Lycalopex culpaeus, Lycalopex griseus y Tyto alba en un ambiente fragmentado de la zona central de Chile. Mastozoología Neotropical (Argentina) 12: 57-60.

FERNÁNDEZ GJ, JC CORLEY \& AF CAPURRO (1997) 
Identification of cougar and jaguar feces through bile acid chromatography. Journal of Wildlife Management 61: 506-510.

GREZ AA, RO BUSTAMANTE, JA SIMONETTI \& L FAHRIG (1997) Landscape ecology, deforestation and habitat fragmentation: the case of the ruil forest in Chile. In: Salinas-Chávez E \& J Middleton (eds) Landscape ecology as a tool for sustainable development in Latin America. http:// www.brocku.ca/epi/lebk/grez.html.

HASLEWOOD GA (1967) Bile salts. Methuen and Company, London, United Kingdom. $116 \mathrm{pp}$.

HELLOU J, A KING \& IH NI (1988) Bile acids from the harp seals, Phoca groenlandic. Comparative Biochemistry and Physiology Part A: Physiology 89: 211-214.

JAKSIC FM (1997) Ecología de los vertebrados de Chile. Ediciones Universidad Católica de Chile, Santiago, Chile. 262 pp.

JIMÉNEZ JE, JL YÁÑEZ \& FM JAKSIC (1996a) Inability of thin-layer chromatography to distinguish feces from congeneric foxes by their bile acid contents. Acta Theriologica 41: 211-215.

JIMÉNEZ JE, JL YÁÑEZ, EL TABILO \& FM JAKSIC (1996b) Niche-complementarity of South-American foxes: reanalysis and test of a hypothesis. Revista Chilena de Historia Natural 69: 113-123.

JOHNSON WE \& WL FRANKLIN (1994) Spatial resource partitioning by sympatric grey fox (Dusicyon griseus) and culpeo fox (Dusicyon culpaeus) in southern Chile. Canadian Journal of Zoology 72: 1788-1793.
JOHNSON MK, R BELDEN \& DR ALDRED (1984) Differentiating mountain lion and bobcat scats. Journal of Wildlife Management 48: 239-244.

KREBS CJ (1989) Ecological methodology. Harper and Row, New York, New York, USA. 654 pp.

LIN DS, WE CONNOR, LK NAPTON \& RF HEIZER (1978) The steroids of 2000-year-old human coprolites. Journal of Lipid Research 19: 215-221.

MAJOR M, MK JOHNSON, WS DAVIS \& TF KELLOG (1980) Identifying scats by recovery of bile acids. Journal of Wildlife Management 44: 290-293.

MILLER SD, J ROTTMANN, KJ RAEDEKE \& RD TABER (1983) Endangered mammals of Chile: status and conservation. Biological Conservation 25: $335-352$.

PRICE MV \& KA KRAMER (1984) On measuring microhabitat affinities with special reference to small mammals. Oikos 42: 349-354.

QUINN T \& WR JACKMAN (1994) Influence of diet on detection of fecal bile acids by thin-layer chromatography. Journal of Wildlife Management 58: 295-299.

ROUGHTON RD \& MW SWEENY (1982) Refinements in scent station methodology for assessing trend in carnivore populations. Journal of Wildlife Management 46: 217-229.

SAAVEDRA B \& JA SIMONETTI (in press) Small mammals of Maulino forest remnants, a vanishing ecosystem of south-central Chile. Mammalia.

SIMONETTI J, A GREZ \& R BUSTAMANTE (2002) El valor de la matriz en la conservación ambiental. Ambiente y Desarrollo (Chile) 18: 116-118, 255-256. 